\title{
GRAIN YIELD AND ENVIRONMENTAL IMPACTS OF ALTERNATIVE RICE (ORYZA SATIVA L.) ESTABLISHMENT METHODS IN MYANMAR
}

\author{
HTwe, T. ${ }^{1}$ - TeChATO, K. $.^{1,2}-$ CHOTIKARN, P. ${ }^{1,3,4}-$ SinUTOK, S. ${ }^{1,4^{*}}$ \\ ${ }^{1}$ Faculty of Environmental Management, Prince of Songkla University, 90110 Songkhla, \\ Thailand \\ ${ }^{2}$ Environmental Assessment and Technology for Hazardous Waste Management Research \\ Center, Prince of Songkla University, 90110 Songkhla, Thailand \\ ${ }^{3}$ Marine and Coastal Resources Institute, Faculty of Environmental Management, Prince of \\ Songkla University, 90110 Songkhla, Thailand \\ ${ }^{4}$ Coastal Oceanography and Climate Change Research Center, Prince of Songkla University, \\ 90110 Songkhla, Thailand \\ *Corresponding author \\ e-mail: ssutinee@gmail.com; phone+66-74-286-847; fax:+66-74-429-758
}

(Received $26^{\text {th }}$ Aug 2020; accepted $18^{\text {th }}$ Dec 2020)

\begin{abstract}
Field experiments were conducted in the summer rice growing season of 2019 in Myanmar, to examine the grain yield and environmental impacts of rice under two alternative crop establishment methods: system of rice intensification (SRI) and modified SRI (MSRI), and two conventional methods: farmers' practices (FP) and direct seeded rice (DSR). A randomized complete block design with five replications was used. In the present study, the leaf area index (LAI) with all tested methods was not significantly different at flowering and harvesting stages. Grain yield and the soil and plant analysis development (SPAD) reading at flowering stage did not significantly differ among the three transplanted methods. However, DSR showed significantly lower yield than FP and MSRI. This reduction might be due to shorter panicle length and fewer spikelets per panicle in DSR. The global warming potentials were 4066.94, 4067.08, 4475.75 and $4136.74 \mathrm{~kg} \mathrm{CO}_{2} \mathrm{eq} \mathrm{ha}^{-1}$ for SRI, MSRI, FP and DSR, respectively. MSRI emitted less greenhouse gas (GHG) than FP with statistically similar grain yield, indicating that it could be a better alternative to other methods. In addition, somewhat closer spacing with two seedlings per hill (MSRI) can further enhance rice yield with higher resource use efficiency in Myanmar or similar agroclimatic regions.
\end{abstract}

Keywords: MSRI, GHGs emission, sustainable, LAI, plant spacing

\section{Introduction}

To feed the growing population, germplasm development and crop production management are important in improving resource use efficiency (Guo et al., 2017; Roberts et al., 2018). Rice cultivation consumes more water than other crops. Water resources are becoming scare as a result of climate change, with a short rainy period and urban consumption patterns. Today's intensive agriculture relies heavily on chemical fertilizers and affects the environment adversely (Iqbal et al., 2019). Combination of organic and inorganic fertilizers can increase grain yield (Hasanuzzaman et al., 2010) and support sustainable crop productivity (Myint et al., 2011). Along with this, farmers need to modify their management practices to adapt to current and further changing demands (GRiSP, 2013). 
Different rice cultivation methods have been adopted depending on the available resources and geographic conditions. Transplanting rice is the predominant practice in Myanmar, as this provides a chance to suppress weed growth before transplanting rice seedlings and favours easy management. However, some farmers in Myanmar are interested in direct seeding of rice, since the labour for transplanting and seedbed preparation can be saved. Weed infestation, however, is a common problem in directly seeded rice (DSR), as rice and weeds germinate at the same time, and land levelling is necessary for effective weed control. The yield of direct seeded rice was lower than that of transplanted rice in Dera Ismail Khan, Pakistan (Javaid et al., 2012). Similarly, early transplanted rice had higher grain yield than directly seeded rice (Kumhar et al., 2016). However, grain yields of direct seeded and transplanted method were not significantly different (Rana et al., 2014). The SRI method resulted higher leaf area index (LAI), grain yield and harvest index (HI) in comparison with a non-SRI method or direct seeded rice in India (Tomar et al., 2018). In Bangladesh, the grain yield under SRI and the recommended transplanting method were statistically similar (Nahar et al., 2018). Different rice varieties respond differently to the SRI method (Kesh et al., 2017). Thus, Stoop et al. (2002) encouraged testing the SRI method for specific environments and considering some changes, for example, in spacing or age of seedling to be transplanted, for successful application.

Harvest index of rice varies by genotype, season, location, nutrient condition and plant density (Amanullah and Inamullah, 2016; Bozorgi et al., 2011; Mohamad, 1994). Leaf area index (LAI) is a well-known growth indicator influenced by variety, plant density, soil nutrient status, $\mathrm{CO}_{2}$, temperature, crop establishment method and season (Fagade and De Datta, 1971; Geethalakshmi et al., 2017). Hirooka et al. (2017) stated that LAI at the heading stage of rice in farmers' filed in Loa PDR, correlated with the grain yield. The soil and plant analysis development (SPAD) chlorophyll meter is widely used nowadays to estimate nitrogen $(\mathrm{N})$ status in leaves. Light intensity in low $\mathrm{N}$ conditions affects the reading, and different points of rice leaves give different measured values (Yuan et al., 2016).

Three main gases: methane $\left(\mathrm{CH}_{4}\right)$, carbon dioxide $\left(\mathrm{CO}_{2}\right)$ and nitrous oxide $\left(\mathrm{N}_{2} \mathrm{O}\right)$ are responsible for increasing global warming potential in agriculture. Rice fields are considered the major source of methane emission which can lead to global warming potential (Arunrat et al., 2016). However, rice is a staple food crop for most people in Southeast Asian countries. Therefore, increasing rice production to accommodate the growing population is crucial while it need to perform better management of rice cultivation method to mitigate greenhouse gas emission (Islam et al., 2018a; Wang et al., 2016). It is demonstrated that decomposition of organic matter in flood rice field is ideal for methanogenesis. Nitrogen fertilizer application method, rate, time and fertilizer type, and water status of field have a significant effect on nitrous oxide emission (Islam et al., 2018b; Millar et al., 2014). Methane production in rice field is affected by number of factors. Application of sulphate containing fertilizer, gypsum, and intermittent irrigation could reduce its emission (Aulakh et al., 2001; Oo et al., 2016). Yi-hu et al. (2014) investigated the effect of different kinds of organic fertilizer on GHGs emission. The results revealed that all organic fertilizer emitted more than non-fertilized treatment. In addition, green manure had greater effect on $\mathrm{CH}_{4}$ emission than animal and biogas residues (Traore et al., 2017).

Myanmar is an agricultural country where agriculture contributes $20 \%$ of the GDP. The actual total sown area of paddy rice was about 7.21 million hectares in 2015-2016, 
comprising monsoon and summer paddy (MOALI, 2016). System of rice intensification method (SRI) was introduced in northern Myanmar and spread to other parts of Myanmar. This is a strategy contributing to climate resilient cultural practices in Myanmar and it is aiming for higher productivity and profitability by using effective natural resources management practices (Hom et al., 2015; MRDS, 2015). The number of seedlings per hill affected the number of panicles per hill and final grain yield (Promsomboon et al., 2019). Therefore, the number of effective tillers for a unit area is one of the most important yield components for increasing the grain yield. One issue with the SRI method is the cost and drudgery for refilling places of the dead seedlings during the recovery period. Based on above mentioned, we modified the SRI method here to have two seedlings per hill, instead of one seedling per hill, to reduce those costs and increase the number of the effective tillers per unit area. This study was conducted to investigate how the alternative crop establishment methods: SRI, MSRI perform and contribute to grain yield, and global warming potential in comparison with FP and DSR.

\section{Materials and methods}

\section{Experimental procedure}

Field experiments were conducted in the summer rice growing season in 2019, at Pwint Phyu Seed Farm (20²1'41.3”N, 9440'24.3”E), in central Myanmar (Fig. 1). A randomized complete block design with five replications was used. The treatments were system of rice intensification (SRI), modified SRI (MSRI), farmer's usual transplanting method (FP) and directly seeded rice (DSR). The SRI and MSRI were considered as alternative rice cultivation methods for the protection and conservation of the limited resources without compromising grain yield. Yadanartoe rice variety was planted in this study since most of the farmers in that region use this variety. The minimum and maximum temperature and rainfall during the experiment were recorded in the experimental farm, and given in Table 1. The rainy weather was observed only in the later growth stage of rice. The soil is silty clay loam with a $\mathrm{pH}$ of 6.59 , total $\mathrm{N}$ of $0.27 \%$, available phosphorus $(\mathrm{P})$ of $0.02 \mathrm{ppm}$, exchangeable potassium (K) of $0.468 \mathrm{cmol}_{\mathrm{c}} \mathrm{kg}^{-1}$, and cation exchange capacity (CEC) of $18.03 \mathrm{cmol}_{\mathrm{c}} \mathrm{kg}^{-1}$. The seeds were soaked for $24 \mathrm{~h}$ and incubated for another $24 \mathrm{~h}$ before seeding. Then, the germinated seeds were sown on well prepared raised beds and seedlings were transplanted to the main field as per treatments (SRI, MSRI, FP). For DSR, the sprouted seeds were planted manually to the line with the seed rate of $80 \mathrm{~kg}$ per acre to compensate the damage from rodents, poor seedlings establishment in low lying spot area, and suppress the growth of weed. Simplifications of some differences among the treatments are shown in Table 2.

Table 1. Weather condition during the experiment

\begin{tabular}{c|c|c|c}
\hline Months & Rainfall (mm) & $\begin{array}{c}\text { Minimum } \\
\text { temperature }\left({ }^{\circ} \mathbf{C}\right)\end{array}$ & $\begin{array}{c}\text { Maximum } \\
\text { temperature }\left({ }^{\circ} \mathbf{C}\right)\end{array}$ \\
\hline 01 March - 31 March & - & 18 & 41 \\
01 April - 30 April & - & 20 & 43 \\
01 May - 31 May & 8.13 & 26 & 43 \\
01 June - 30 June & 72.13 & 21 & 43 \\
01 July - 05 July & 5.08 & 25 & 36 \\
\hline
\end{tabular}


Table 2. Simplification of some components in different rice cultivation methods

\begin{tabular}{|c|c|c|c|c|}
\hline Components & $\begin{array}{c}\text { System of rice } \\
\text { intensification (SRI) }\end{array}$ & \begin{tabular}{|l|} 
Modified system of rice \\
intensification (MSRI)
\end{tabular} & $\begin{array}{c}\text { Farmers' practices } \\
\text { (FP) }\end{array}$ & $\begin{array}{c}\text { Direct seeded rice } \\
\text { (DSR) }\end{array}$ \\
\hline $\begin{array}{l}\text { Farmyard manure at final } \\
\text { land preparation }\left(\mathrm{t} \mathrm{ha}^{-1}\right)\end{array}$ & 15 & 15 & - & - \\
\hline $\begin{array}{l}\text { Chemical fertilizer (N- } \\
\mathrm{P}_{2} \mathrm{O}_{5}-\mathrm{K}_{2} \mathrm{O} \mathrm{kg} \mathrm{ha-1)}\end{array}$ & $5-5-5$ & $5-5-5$ & $53-29-37$ & $53-29-37$ \\
\hline \multicolumn{5}{|l|}{ Application time } \\
\hline - At final land preparation & - & - & $\begin{array}{c}\text { Full dose of } \mathrm{P}_{2} \mathrm{O}_{5}, 1 / 3 \\
\text { dosage of nitrogenous } \\
\text { fertilizer and half dose of } \\
\mathrm{K}_{2} \mathrm{O}\end{array}$ & $\begin{array}{c}\text { Full dose of } \mathrm{P}_{2} \mathrm{O}_{5}, 1 / 3 \\
\text { dosage of nitrogenous } \\
\text { fertilizer and half dose of } \\
\mathrm{K}_{2} \mathrm{O}\end{array}$ \\
\hline $\begin{array}{l}-2 \text { weeks after } \\
\text { transplanting }\end{array}$ & $\begin{array}{l}\text { Half dose of } \mathrm{N}, \mathrm{P}_{2} \mathrm{O}_{5}, \\
\mathrm{~K}_{2} \mathrm{O}\end{array}$ & $\begin{array}{l}\text { Half dose of } \mathrm{N}, \mathrm{P}_{2} \mathrm{O}_{5}, \\
\mathrm{~K}_{2} \mathrm{O}\end{array}$ & $\begin{array}{c}1 / 3 \text { dosage of } \\
\text { nitrogenous fertilizer }\end{array}$ & \\
\hline - 4 weeks after seeding & & & & $\begin{array}{c}1 / 3 \text { dose of nitrogenous } \\
\text { fertilizer }\end{array}$ \\
\hline - Panicle initiation (PI) & $\begin{array}{l}\text { Half dose of N, } \mathrm{P}_{2} \mathrm{O}_{5}, \\
\mathrm{~K}_{2} \mathrm{O}\end{array}$ & $\begin{array}{l}\text { Half dose of N, } \mathrm{P}_{2} \mathrm{O}_{5}, \\
\qquad \mathrm{~K}_{2} \mathrm{O}\end{array}$ & $\begin{array}{c}1 / 3 \text { dose of nitrogenous } \\
\text { fertilizer and half dose of } \\
\mathrm{K}_{2} \mathrm{O}\end{array}$ & $\begin{array}{l}1 / 3 \text { dose of nitrogenous } \\
\text { fertilizer and half dose of } \\
\qquad \mathrm{K}_{2} \mathrm{O}\end{array}$ \\
\hline $\begin{array}{c}\text { Transplanting } \\
\text { (seedling(s)/hill) }\end{array}$ & 1 & 2 & 3 to 4 & Directly seeded \\
\hline Seedling age (days) & 15 & 15 & 30 & - \\
\hline Spacing $\left(\mathrm{cm}^{2}\right)$ & $25 \times 25$ & $25 \times 25$ & $20 \times 20$ & $25 \mathrm{~cm}$ between row \\
\hline Water level & $\begin{array}{c}\text { Moist condition at } \\
\text { vegetative growth stage } \\
\text { and } 2-5 \mathrm{~cm} \text { from PI to } \\
2 \text { weeks before harvest } \\
\text { was maintained }\end{array}$ & \begin{tabular}{|c|} 
Moist condition at \\
vegetative growth stage \\
and $2-5 \mathrm{~cm}$ from PI to \\
2 weeks before harvest \\
was maintained
\end{tabular} & $\begin{array}{c}2-8 \mathrm{~cm} \text { of water level } \\
\text { was kept throughout } \\
\text { growing season up to } \\
2 \text { weeks before harvest }\end{array}$ & $\begin{array}{l}2-8 \mathrm{~cm} \text { of water level } \\
\text { was kept throughout } \\
\text { growing season up to } \\
2 \text { weeks before harvest }\end{array}$ \\
\hline
\end{tabular}

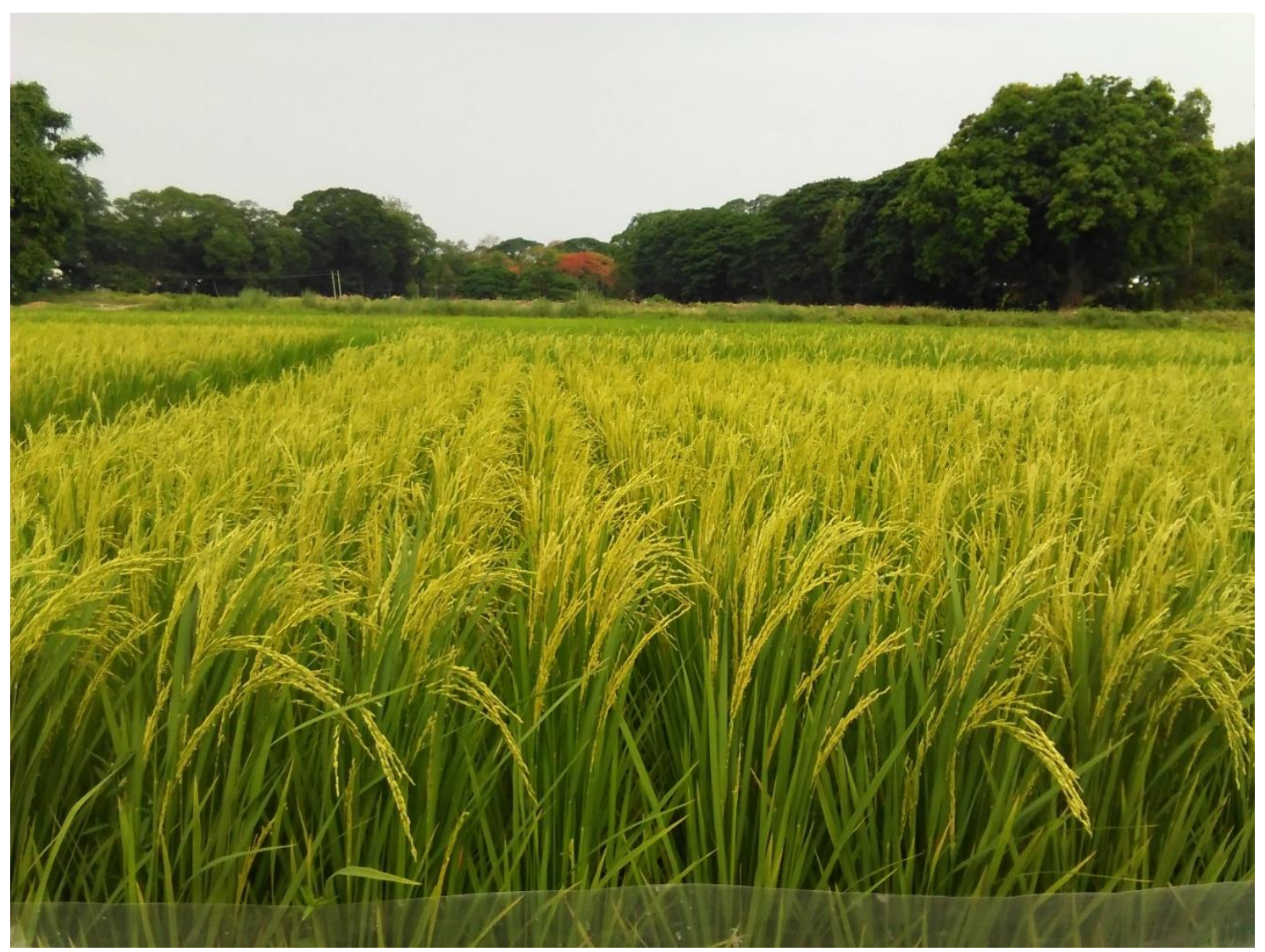

Figure 1. Overview of the experiment 
A multipseQ device (PhotosynQ, United States) was used for photosynthetic efficiency measurement (maximum and effective quantum yield, and chlorophyll (SPAD) reading) (Kuhlgert et al., 2016; Ndikuryayo et al., 2020). The fully developed uppermost leaf was measured at the $1 / 3$ from the leaf tip position for four random hills per plot, and the averages were used to get the mean value by treatment. Measurements were taken from 10:00 to 11:00. The maximum quantum yield was measured at predawn (Shanker et al., 2019).

Each plot occupied $7.5 \mathrm{~m} \times 21 \mathrm{~m}$ and the plots were surrounded by bunds $(0.3 \mathrm{~m}$ height $\times 0.3 \mathrm{~m}$ width), and the bunds were separated by $1 \mathrm{~m}$ wide alleys (Pimratch et al., 2015). At the harvesting time, $5 \mathrm{~m} \times 5 \mathrm{~m}$ at the center of the plot was harvested for grain yield determination, which was converted to $\mathrm{kg} \mathrm{ha}^{-1}$. The moisture content of rice was $14 \%$ (dry weight basis). Straw was over dried at $70^{\circ} \mathrm{C}$ until constant weight and the dry weight of straw was recorded. Twelve randomly hills from each plot were selected, and the average value per plot was used for the yield components and plant height data (Chen et al., 2019). The plant height was measured from the base of the plant to the longest leaf tip at early tillering stage, panicle initiation (PI; BBCH 34) and flowering stages (BBCH 61) while it was measured from the base of the plants to the tip of panicle at harvesting stage (BBCH 89; Lancashire et al., 1991). ImageJ software was applied for the leaf area measurement (Savvides and Fotopoulos, 2018). The leaf area index and harvest index were calculated with Equations 1 and 2 (Yoshida, 1981).

$$
\begin{aligned}
& \text { Leaf area index }(L A I)=\frac{\text { Total leaves area }\left(\mathrm{cm}^{2}\right)}{\text { Ground area where the leaves have been taken }\left(\mathrm{cm}^{2}\right)} \\
& \text { Harvest index }(\mathrm{HI}) \%=\frac{\text { Dry weight of grain yield }\left(\mathrm{kg} \mathrm{ha}^{-1}\right)}{\text { Dry weight of the total aboveground biomass }\left(\mathrm{kg} \mathrm{ha}^{-1}\right)}
\end{aligned}
$$

\section{Greenhouse gas emissions}

The greenhouse gas emission was calculated with the following formulas (Arunrat and Pumijumnong, 2017; IPCC, 2006; Tubiello et al., 2015; Yodkhum et al., 2018) and calculation was considered within the farm gate. The global warming potential (GWP) conversion parameters of $\mathrm{CO}_{2}, \mathrm{CH}_{4}$ and $\mathrm{N}_{2} \mathrm{O}$ (over 100 years) were 1,25 and $298 \mathrm{~kg} \mathrm{ha}^{-1}$ $\mathrm{CO}_{2}$ equivalent (IPCC, 2007). Imidacloprid (70\% WP) insecticide was used in this experiment and emission factors were presented in Table 3. Annual methane emission for 1 ha was estimated by the multiplication of adjusted daily emissions factor $\left(\mathrm{EF}_{\mathrm{i}}\right)$ with the duration of rice (days) (Eqs. 3 and 4). The fields under FP and DSR were continuously flooded, and weeding was done by manually.

$$
\mathrm{EF}_{\mathrm{i}}=\mathrm{EF}_{\mathrm{c}} \times \mathrm{SF}_{\mathrm{w}} \times \mathrm{SF}_{\mathrm{p}} \times \mathrm{SF}_{0}
$$

where: $\mathrm{EF}_{\mathrm{c}}=$ baseline emissions factor for continuously flooded field without organic amendments, $\mathrm{SF}_{\mathrm{w}}=$ a scaling factor for varying water status in rice cultivation, $\mathrm{SF}_{\mathrm{p}}=\mathrm{a}$ scaling factor for water status of field before cultivation, $\mathrm{SF}_{0}=\mathrm{a}$ scaling factor for farmyard manure (FYM) application.

$$
\mathrm{SF}_{\mathrm{n}}=\left(1+\sum_{\mathrm{i}} \mathrm{ROA}_{\mathrm{i}} \times \mathrm{CFOA}_{\mathrm{i}}\right)^{0.59}
$$


where: $\mathrm{ROA}_{i}=$ amount of farmyard manure applied $\left(\mathrm{t} \mathrm{ha}^{-1}\right), \mathrm{CFOA}_{\mathrm{i}}=$ conversion factor for farmyard manure i.

Direct and indirect emissions by synthetic fertilizer were calculated by Equations 5 and 6 (IPCC, 2006).

$$
\begin{aligned}
& \text { Direct } \mathrm{N}_{2} \mathrm{O} \text { emissions }\left(\mathrm{kg} \mathrm{N}_{2} \mathrm{O} \mathrm{yr}^{-1}\right)=\left(\mathrm{F}_{\mathrm{SN}} \times 0.01 \times 44 / 28\right) \\
& \text { Indirect } \mathrm{N}_{2} \mathrm{O} \text { emissions }\left(\mathrm{kg} \mathrm{N}_{2} \mathrm{O} \mathrm{\textrm {yr } ^ { - 1 }}\right)=\left[\left(\mathrm{F}_{\mathrm{SN}} \times \mathrm{Frac}_{\mathrm{CASF}} \times 0.01\right)+\left(\mathrm{F}_{\mathrm{SN}} \times \text { Frac }_{\text {leach }} \times 0.0075\right)\right] \times 44 / 28(\mathrm{Eq} .6)
\end{aligned}
$$

where: $F_{\text {rac }}{ }_{\mathrm{GASF}}=$ fraction of synthetic fertilizer that volatilizes as $\mathrm{NH}_{3}$ and $\mathrm{NO}_{\mathrm{x}}$, Frac ${ }_{\text {Leach }}=$ fraction of synthetic fertilizer that leaches as $\mathrm{NH}_{3}$ and $\mathrm{NO}_{\mathrm{x}}$.

\begin{tabular}{|c|c|c|c|}
\hline Activity & Emission factor & Unit & References \\
\hline Diesel & 2.76 & $\mathrm{kgCO}_{2} \mathrm{eq} \mathrm{L}^{-1}$ & Ilahi et al., 2019 \\
\hline Insecticide & 5.1 & $\mathrm{kgCO}_{2}$ eq $\mathrm{kg}^{-1}$ & Arunrat and Pumijumnong, 2017; Lal et al., 2004 \\
\hline $\mathrm{EF}_{\mathrm{c}}$ & 1.3 & $\mathrm{kgCH}_{4}$ ha $^{-1}$ day $^{-1}$ & IPCC, 2006 \\
\hline $\mathrm{SF}_{\mathrm{w}}$ & $0.52=$ SRI and MSRI, $1=$ FP and DSR & & IPCC, 2006 \\
\hline $\mathrm{SF}_{\mathrm{p}}$ & 1 in all methods & & IPCC, 2006 \\
\hline CFOAi & 0.14 & & IPCC, 2006 \\
\hline Frac $_{\text {Leach }}$ & 0.3 & Kg.N kg ${ }^{-1} \mathrm{~N}$ applied & Tubiello et al., 2015 \\
\hline $\operatorname{Frac}_{\mathrm{GASF}}$ & 0.1 & $\mathrm{Kg} \cdot \mathrm{NH}_{3}-\mathrm{N} .+\mathrm{NO}_{\mathrm{x}}-\mathrm{N} \cdot \mathrm{kg}^{-1} \mathrm{~N}$ applied & Tubiello et al., 2015 \\
\hline
\end{tabular}

Table 3. Emission factors for the calculation of greenhouse gas

\section{Statistical analysis}

One-way ANOVA was performed to test the differences among the treatments means. Comparison of means were made by Tukey's test at 5\% level of confidence. Before conducting ANOVA, a homogeneity test (Levene's test) and a normality test (Kolmogorov-Smirnov) were carried out.

\section{Results}

\section{Plant height (cm)}

The plant height of rice under the different rice cultivation methods at tillering, PI, flowering and harvesting stages is shown in Figure 2. At the tillering stage, the heights with SRI, MSRI and DSR did not significantly differ. The FP method showed the shortest plant height among the treatments $(\mathrm{P}<0.001)$. At $\mathrm{PI}$ stage, there was no significantly different $(\mathrm{P}>0.05)$. As for flowering stage, the tallest plants were observed with the SRI method, which was on par with the MSRI. The shortest plant height occurred under FP, without significantly difference from DSR $(\mathrm{P}<0.001)$. The plants grown under SRI and MSRI were significantly higher than those under FP and DSR at harvesting stage $(\mathrm{P}<0.001)$.

\section{Leaf area index (LAI)}

Rice cultivation methods affected LAI at different growth stages (Fig. 3). The highest LAI with MSRI and DSR methods achieved at PI stage, while the FP method 
showed the highest LAI at flowering stage. At PI stage, LAI of MSRI and DSR was significantly higher than those of the other three methods $(\mathrm{P}<0.001)$. Regarding LAI at flowering stage, the higher LAI values were observed under MSRI, FP and DSR although there were no significantly different among the treatments $(P>0.05)$. All methods showed statistically similar LAI at harvesting stage $(\mathrm{P}>0.05)$.

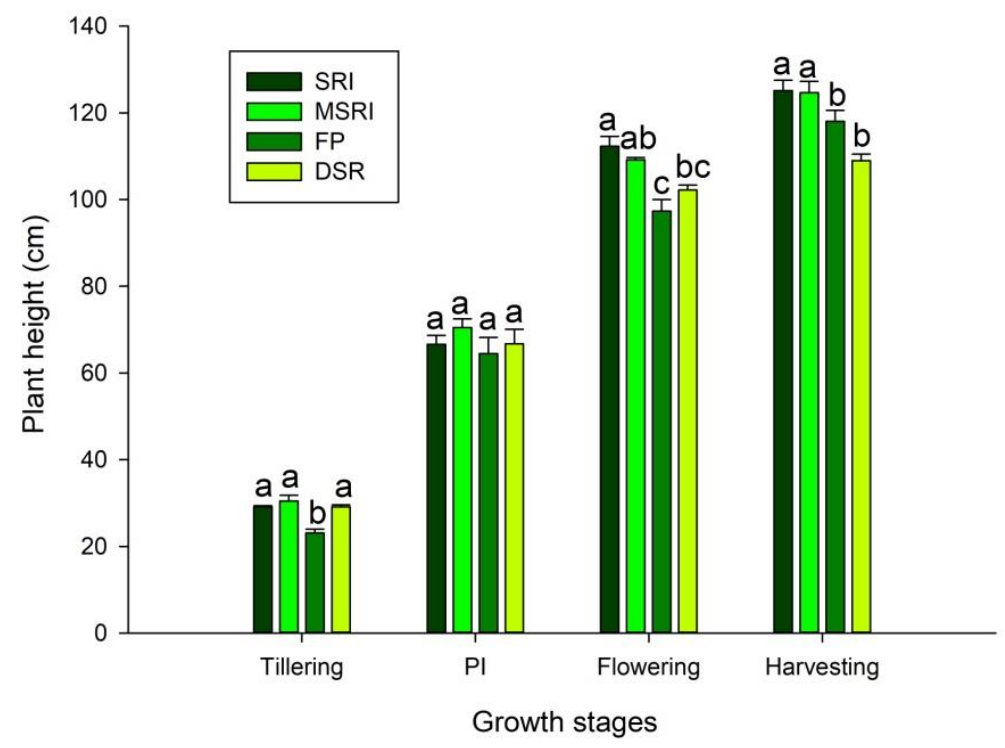

Figure 2. Plant heights by four rice cultivation methods at different growth stages.

SRI = System of Rice Intensification, MSRI = Modified System of Rice Intensification, $F P=$ Farmer's practices, $D S R=$ Direct Seeded Rice, $P I=$ Panicle initiation. Bars indicate mean $\pm S E(n=5)$. Significant differences are shown by different lowercase letters $(P<0.05)$

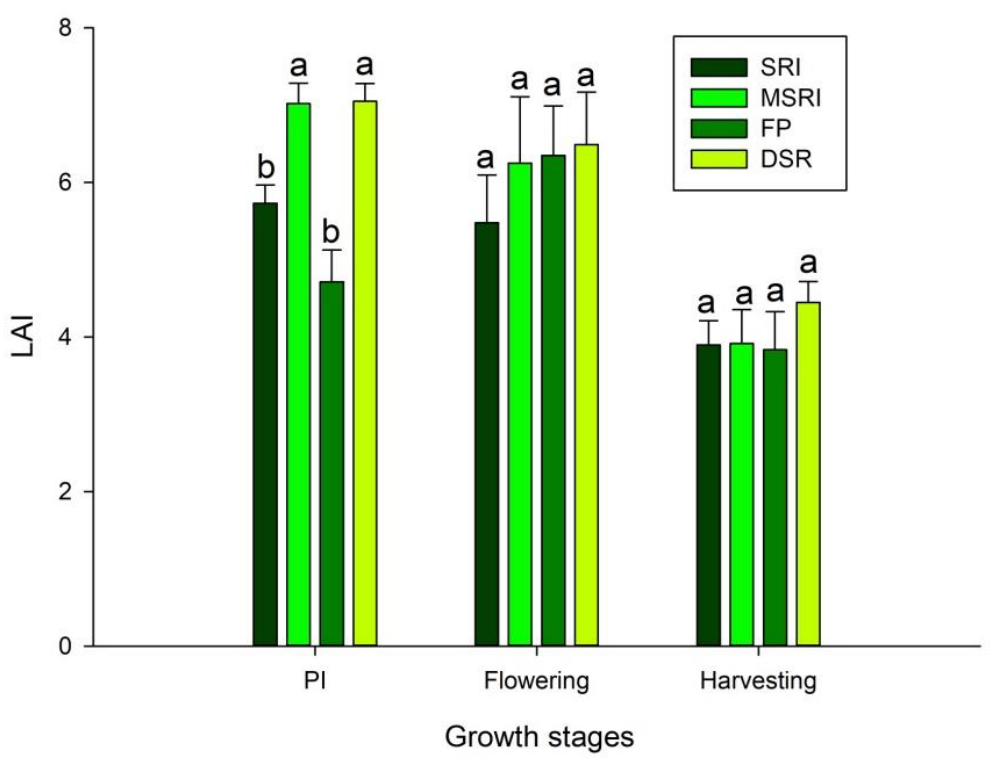

Figure 3. Leaf area index (LAI) by rice cultivation method at different growth stages. $S R I=$ System of rice intensification, MSRI = Modified system of rice intensification, $F P=$ Farmers ' practices, $D S R=$ Direct seeded rice, $P I=$ Panicle initiation. Bars indicate mean $\pm S E(n=5)$. Significant differences are shown by different lowercase letters $(P<0.05)$ 


\section{Number of tillers $\mathrm{m}^{-2}$}

Number of tillers $\mathrm{m}^{-2}$ was significantly affected by planting method. At tillering stage, the most number of tillers $\mathrm{m}^{-2}$ was observed with DSR, followed by MSRI, FP and SRI $(\mathrm{P}<0.001)$. At PI stage, similar trend was observed, in that, the SRI method had significantly lower number of tillers than the other methods $(\mathrm{P}<0.001)$. At flowering stage, the number of tillers with three transplanted methods were not significantly different while DSR produced the most number of tillers $\mathrm{m}^{-2}$ among the treatments (Fig. 4; $\mathrm{P}<0.001$ ).

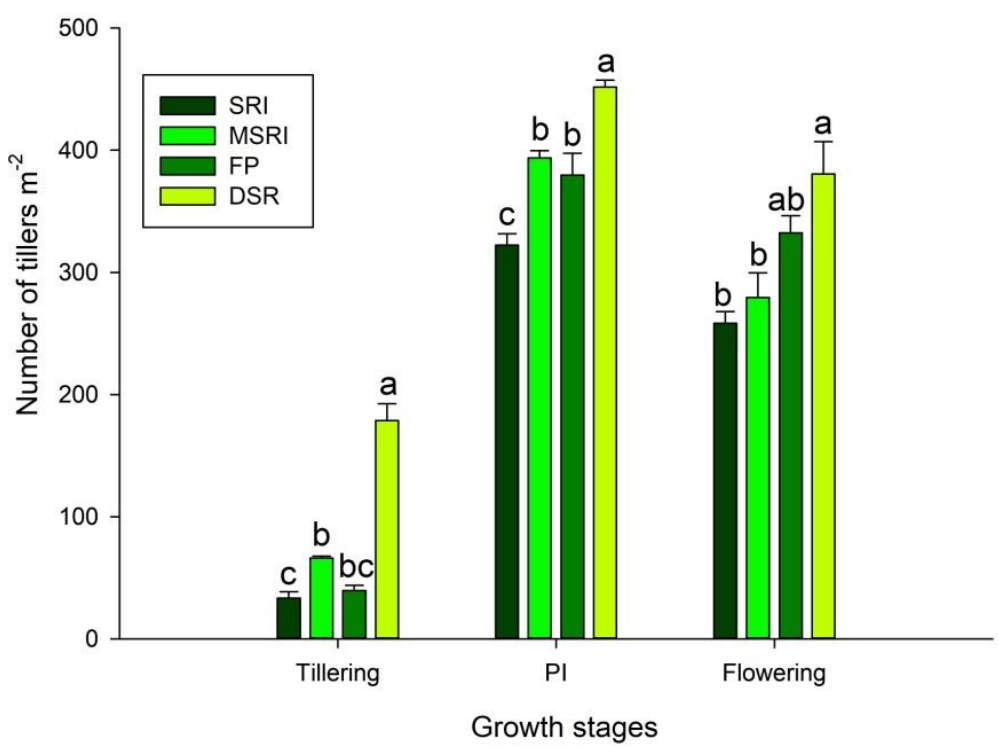

Figure 4. Number of tillers by rice cultivation method at different growth stages. SRI $=$ System of rice intensification, MSRI = Modified system of rice intensification, FP = Farmers'

Practices, DSR = Direct seeded rice, $P I=$ Panicle initiation. Bars indicate mean $\pm S E(n=5)$. Significant differences are shown by different lowercase letters $(P<0.05)$

\section{Chlorophyll SPAD value and Phi2 in light and in the dark conditions}

Chlorophyll content (SPAD) is an indirect indicator of nitrogen status of the leaf. The chlorophyll content, in this study, was measured with the multispeQ device. SPAD values of all the treatments were statistically similar at PI stage $(P>0.05)$. SRI and MSRI methods showed significantly higher chlorophyll content than DSR $(P=0.012)$ at flowering stage, while there were no significantly different among three transplanted treatments. Chlorophyll contents under DSR and FP were not statistically different (Fig. 5). Phi2 (fraction of light utilized for photochemistry) in daytime and in the dark condition was not affected by the planting method (Fig. 6; P > 0.05).

\section{Grain yield and its attributes}

Effects of rice cultivation methods on yield components are shown in Table 4. Among the yield components, there were no significantly differences in 1000-grain weight, number of panicles $\mathrm{m}^{-2}$ and filled grain percentages. The SRI and MSRI methods showed significantly longer panicles than FP and DSR $(\mathrm{P}<0.001)$. Panicle lengths of SRI and MSRI were statistically similar. Furthermore, the SRI and MSRI 
produced more spikelets per panicle than FP and DSR $(\mathrm{P}<0.001)$. The least number of spikelets per panicle was observed with DSR.

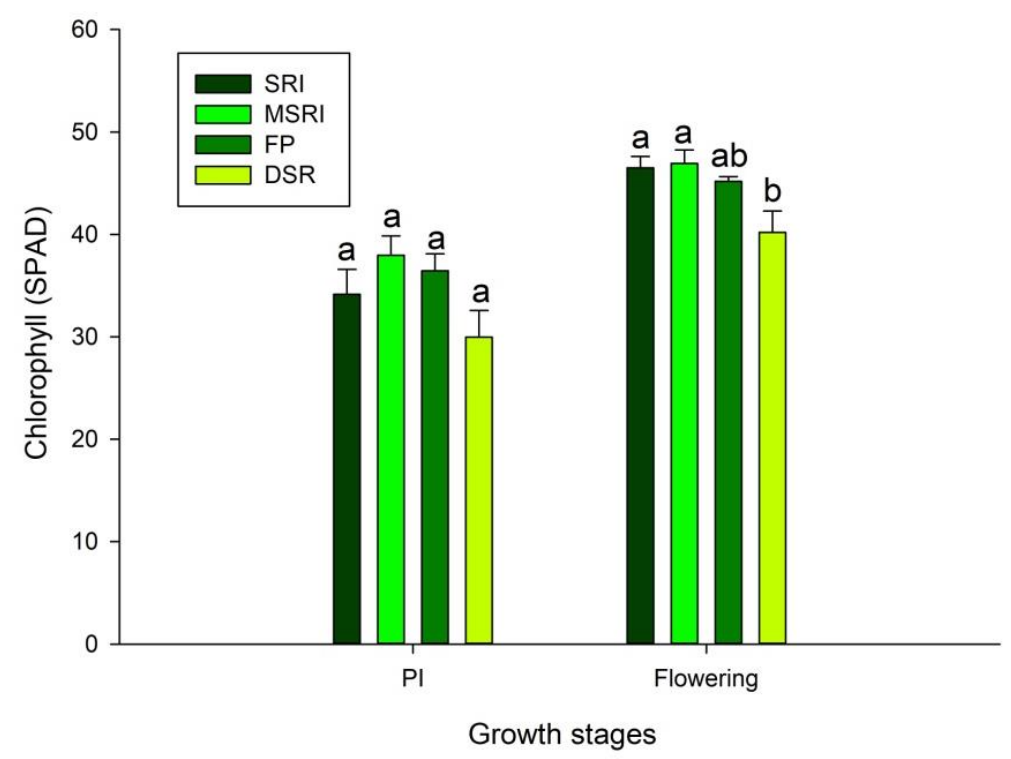

Figure 5. Chlorophyll content (SPAD) by rice cultivation method at PI and flowering stages.

$S R I=$ System of rice intensification, MSRI $=$ Modified system of rice intensification,

$F P=$ Farmers' Practices, $D S R=$ Direct seeded rice, $P I=$ Panicle initiation. Bars indicate mean $\pm S E(n=5)$. Significant differences are shown by different lowercase letters $(P<0.05)$

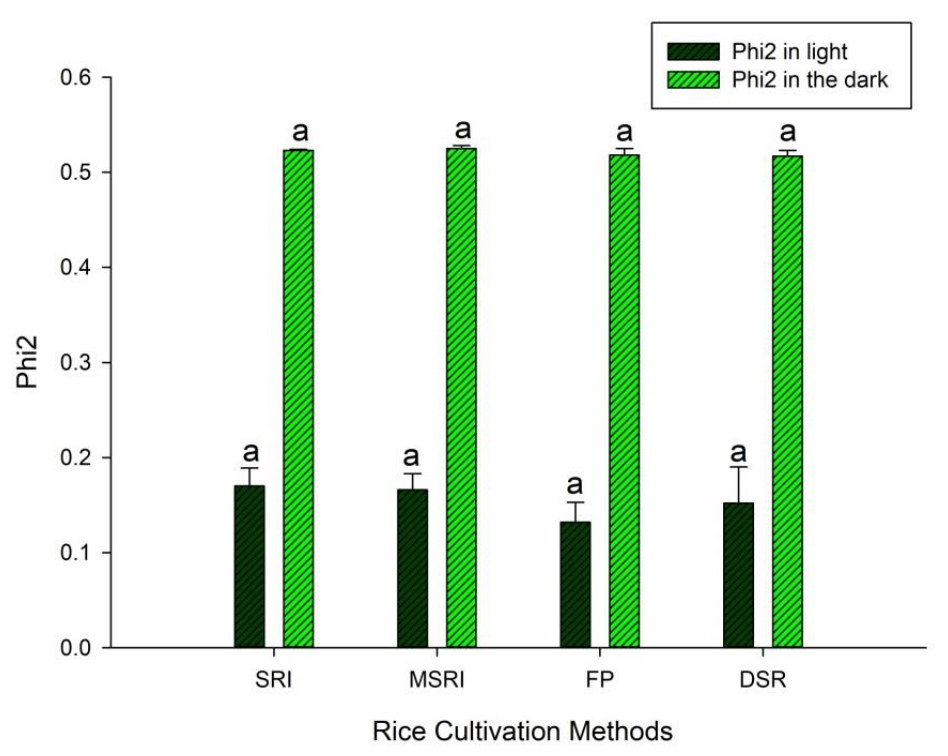

Figure 6. Phi2 by rice cultivation method in light and in the dark conditions at flowering stage. $S R I=$ System of rice intensification, MSRI = Modified system of rice intensification, $F P=$ Farmers' practices, $D S R=$ Direct seeded rice. Bars indicate mean $\pm S E(n=5)$

Grain yield of SRI, MSRI and FP methods were not significantly different, while DSR produced a significantly lower grain yield than other tested methods (Table 5; 
$\mathrm{P}=0.013)$. The yield of SRI and DSR were statistically similar. Harvest index of rice was not affected by cultivation methods in this study $(\mathrm{P}>0.05)$.

Table 4. Yield components and panicle lengths of different rice cultivation methods $($ mean $\pm S E)$

\begin{tabular}{c|c|c|c|c|c}
\hline Treatment & 1000-grain weight $(\mathbf{g})$ Spikelets panicle $^{-\mathbf{1}}$ & ${\text { Number of panicles } \mathbf{~ m}^{-2}}$ Filled grain $\mathbf{( \% )}^{\text {Panicle length }(\mathbf{c m})}$ \\
\hline SRI & $25.38 \pm 0.23$ & $135.48 \pm 8.05 \mathrm{a}$ & $254.82 \pm 16.96$ & $91.20 \pm 0.76$ & $28.17 \pm 0.23 \mathrm{a}$ \\
MSRI & $25.00 \pm 0.13$ & $131.18 \pm 4.13 \mathrm{a}$ & $268.99 \pm 27.44$ & $89.50 \pm 0.64$ & $26.78 \pm 0.46 \mathrm{a}$ \\
FP & $25.50 \pm 0.80$ & $94.23 \pm 7.47 \mathrm{~b}$ & $283.11 \pm 20.35$ & $86.94 \pm 1.78$ & $23.96 \pm 0.52 \mathrm{~b}$ \\
DSR & $25.46 \pm 0.55$ & $61.98 \pm 2.74 \mathrm{c}$ & $328.66 \pm 23.25$ & $89.40 \pm 1.43$ & $23.78 \pm 1.01 \mathrm{~b}$ \\
Significance & $\mathrm{ns}$ & $* * *$ & $\mathrm{~ns}$ & $\mathrm{~ns}$ & $* * *$ \\
\hline
\end{tabular}

SRI $=$ System of rice intensification, MSRI $=$ Modified system of rice intensification, FP $=$ Farmers ${ }^{\prime}$ practices, DSR $=$ Direct seeded rice. Significant differences are shown by different lowercase letters $(\mathrm{P}<0.05)$. ${ }^{* * *}=$ significantly different at $\mathrm{P}<0.001$, ns $=$ non-significant

Table 5. Grain yield and harvest index by rice cultivation method (mean $\pm S E$ )

\begin{tabular}{c|c|c}
\hline Treatment & Grain Yield $\left(\mathbf{k g ~ h a}^{\mathbf{- 1}}\right)$ & Harvest Index (\%) \\
\hline SRI & $6587.79 \pm 267.98 \mathrm{ab}$ & $52.78 \pm 1.14$ \\
MSRI & $6662.95 \pm 182.63 \mathrm{a}$ & $52.59 \pm 2.67$ \\
FP & $6819.65 \pm 178.37 \mathrm{a}$ & $56.33 \pm 1.72$ \\
DSR & $5816.29 \pm 158.01 \mathrm{~b}$ & $49.37 \pm 1.70$ \\
Significance & $*$ & $\mathrm{~ns}$ \\
\hline
\end{tabular}

$\mathrm{SRI}=$ System of rice intensification, MSRI $=$ Modified system of rice intensification, FP $=$ Farmers' practices, DSR $=$ Direct seeded rice. Significant differences are shown by different lowercase letters $(\mathrm{P}<0.05) . *=$ significantly different at $\mathrm{P}<0.05, \mathrm{~ns}=$ non-significant

\section{Greenhouse gas emissions}

The calculated greenhouse gas emission of different rice cultivation methods is depicted in Figure 7. The global warming potentials were 4066.94, 4067.08, 4475.75 and $4136.74 \mathrm{~kg} \mathrm{CO}_{2} \mathrm{eq} \mathrm{ha}^{-1}$ for SRI, MSRI, FP and DSR, respectively. Higher $\mathrm{N}_{2} \mathrm{O}$ emission was occurred under FP and DSR, which was contributed from higher amount of chemical fertilizer application than those under SRI and MSRI (alternative methods). In the case of methane emission, the application of FYM $\left(15 \mathrm{t} \mathrm{ha}^{-1}\right)$ accounted for increasing emission of $\mathrm{CH}_{4}$ under SRI and MSRI methods.

\section{Discussion}

Potentially facing water scarcity, climate change and soil degradation, agricultural practices that will sustain productivity for future generations are crucial. Performances of different rice establishment methods were evaluated experimentally in this study. The plant heights of SRI and MSRI were generally taller than those of FP and DSR, indicating better crop growth of the former. However, number of tillers $\mathrm{m}^{-2}$ was affected by cultivation method at all growth stages, with the lowest value generally provided by the SRI method. This in turn was mainly affected by the number of hill $\mathrm{m}^{-2}$. At harvesting stage, the FP method produced 10 and $5 \%$ more effective tillers $\mathrm{m}^{-2}$ than SRI and MSRI, respectively, in the present study (Table 4). In a previous study, grain yield 
reduction due to lower plant density could not be offset by increased application of $\mathrm{N}$ fertilizer (Huang et al., 2013). Therefore, optimum plant population per unit area is important for increasing grain yield.

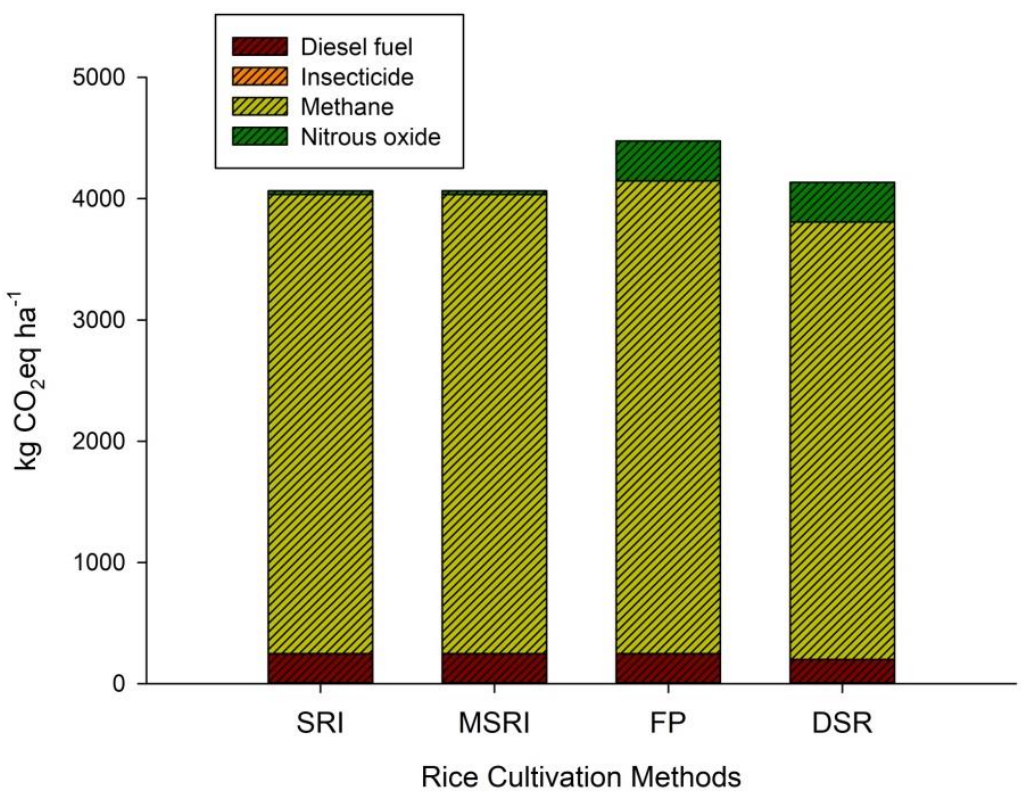

Figure 7. Greenhouse gas emission from different rice cultivation methods. SRI = System of rice intensification, $M S R I=$ Modified system of rice intensification, $F P=$ Farmers' practices, $D S R=$ Direct seeded rice

Leaf area index is an important parameter affecting grain yield of rice. Leaf area index of rice is influenced by leaf size and number of leaves per unit area (Tanaka and Kawano, 1965). In the present study, rice cultivation methods affected leaf area index significantly at PI stage. The MSRI and DSR attained the higher LAI than the others, which was mainly attributed by number of leaves per field area. Our results are in line with the report of Gautam et al. (2019), which revealed SRI with some modification gave higher LAI than conventional transplanted rice at PI stage in India. In addition, dry direct seeded rice achieved higher LAI than traditional transplanted rice (Ishfaq et al., 2020). The earlier studies of Sen et al. (2014) and Singh et al. (2014) reported that a wider spacing gave greater LAI value for transplanted rice than a closer one. At flowering and harvesting stages, all rice establishment methods had statistically similar LAI. The MSRI method gave the highest LAI at PI stage, which then decreased gradually towards the harvesting stage. This might be due to the drying of some tillers in the later growth stages.

Chlorophyll content (SPAD) is an indirect indicator of nitrogen status of the leaf. Chlorophyll content at PI stage was influent on grain yield of rice (Ramesh et al., 2002; Gholizadeh et al., 2017). In addition, leaf $\mathrm{N}$ content at flowering stage is also important for grain filling and it was positively and significantly correlated with grain yield (Ghosh et al., 2020). In the present study, SPAD value under DSR was low although there was not significantly different from others at PI stage. The SPAD values of SRI, MSRI and FP were statistically similar at flowering stage. However, SRI and MSRI had more leaf nitrogen than DSR. This might be due to higher plant populations per unit 
area in DSR, competing for the resources. Phi2 is the fraction of light that is used for photochemistry (Kramer et al., 2004). Phi2 in both light and dark conditions were not affected by planting method in this study. Similarly, different $N$ levels did not significantly affect Phi 2 of rice in a hydroponic experiment (Shrestha, 2012). However, SRI with $20 \mathrm{~cm} \times 20 \mathrm{~cm}$, resulted in higher chlorophyll content, maximum and effective quantum of PSII than the recommended rice transplanted method in India. Effective quantum yield of PSII (Phi2) was affected by crop management practices under unstressed conditions (Thakur et al., 2010a).

There was no significant difference in grain yield among SRI, MSRI and FP. In fact, production with SRI was statistically similar to DSR. In other words, MSRI and FP yielded significantly more than DSR. That higher yield was mainly contributed by a greater number of spikelets per panicle, and longer panicle length of the former. Although, DSR had more panicles per unit area, it could not compensate for a smaller number of spikelets per panicle. Our results are supported by Huang et al. (2011). They reported shorter panicles length and a smaller number of spikelets per panicle was observed under DSR and this was related to the poorer nutritional status with DSR in comparison with transplanted rice. Birhane (2013) reported that panicle length of transplanted rice was significantly longer than that of direct seeded rice. In a previous study, transplanted rice gave higher grain yield than DSR (Dileep et al., 2018; Hossain et al., 2002). However, the productions of direct seeded and transplanted rice were statistically similar in the reports of Liu et al. (2015) and Kar et al. (2018). The effectiveness of weed control in DSR might be one of the reasons for differences in grain yield. Harvest index (HI) is the ratio of paddy rice to total plant biomass, excluding the root. In the present study, HI of rice was affected by cultivation method. Similarly, HI with SRI and recommended management practices (RMP) were statistically similar (Thakur et al., 2010b). However, Chandankute et al. (2015) reported grain and HI under SRI method were higher than that under FP. This might be due to differences in agroclimatic conditions. A $20 \mathrm{~cm} \times 20 \mathrm{~cm}$ spacing with 3 seedlings per hill achieved the highest $\mathrm{HI}$ in Iran (Bozorgi et al., 2011).

Rice cultivation emits greenhouse gases: carbon dioxide, methane and nitrous oxide which contribute global warming potential (GWP). Methane emission from the rice field is affected by water regime, crop duration and manure application in the present study. Methane emission under DSR was a little bit lower than those under SRI and MSRI methods in this study. However, in a previous report, SRI and wet seeded rice emitted 26.8 and $16.6 \%$ lesser $\mathrm{CH}_{4}$ over transplanted method, respectively (Ramesh and Rathika, 2020). It might be due to differences in fertilizer application. In addition, Fazli and Man (2014) reported that modifications of current rice cultivation method in Malaysia can suppress $\mathrm{CH}_{4}$ emission. In the present study, the GWP were 4066.94, 4067.08, 4475.75 and $4136.74 \mathrm{~kg} \mathrm{CO}_{2}$ eq ha ${ }^{-1}$ for SRI, MSRI, FP and DSR, respectively. These were within the range of the report by Arunrat and Pumijumnong (2017). FYM was responsible for elevating GHGs emission in alternative rice cultivation methods while nitrogenous fertilizer compounded to anoxia effect for increasing it in FP and DSR. Application of organic manure increased GHGs emission compared with nonfertilized treatment. The effect is more obvious in conventional method than that in SRI (Ly et al., 2013). Some other reports revealed the effect of farmyard manure on GHGs emission although it depends on many factors, for instance, time of FYM application (Linquist et al., 2012; Pokhrel and Soni, 2019; Ren et al., 2017). The lower value of GHGs emission was observed in DSR method than that in FP 
in the present study, which could be explained by different in lower fuel consumption for tillage operation and crop duration. However, weed infestation was serious in DSR, hence, the field was continuously flooded. That anoxia condition attributed to comparatively high $\mathrm{CH}_{4}$ emission under direct seeded rice in the present study.

\section{Conclusions}

Farming practices that preserve the natural resources and ensure economic returns are crucial for sustainable agriculture. Effective quantum yield of PSII and maximum quantum yield of PSII were not affected by cultivation method. This study concluded that SPAD value at flowering stage and grain yield of system of rice intensification (SRI), modified system of rice intensification (MSRI) and farmers' practices (FP) were not significantly different. Direct seeded rice (DSR) produced the lowest grain yield among the tested methods. Global warming potentials of SRI and MSRI were approximately $10 \%$ lower than that of FP. Of the two superior cultivation methods in term of grain yield, the MSRI method utilized fewer resources (inputs) of chemical fertilizer, seeds and water, in comparison with the FP method. Further adjustment of plant spacing with optimum combination of organic and chemical fertilizers was recommended to make agriculture more productive and sustainable.

Acknowledgements. This research was funded by the Interdisciplinary Graduate School of Energy System Scholarship (IGS-Energy 2017/2-004), Faculty of Environmental Management, Prince of Songkla University (PSU) (SD-ENV 01/2019) and Graduate School of PSU. The authors thank Assoc. Prof. Dr. Seppo Karrila and the Research and Development Office, PSU for assistance with proofing the English. First author is grateful to Department of Agriculture, Ministry of Agriculture, Livestock and Irrigation of Myanmar for offering the resources in conducting the experiment.

\section{REFERENCES}

[1] Amanullah, Inamullah (2016): Dry matter partitioning and harvest index differ in rice genotypes with variable rates of phosphorus and zinc nutrition. - Rice Science 23(2): 7887.

[2] Arunrat, N., Pumijumnong, N. (2017): Practices for reducing greenhouse gas emissions from rice production in Northeast Thailand. - Agriculture 7.

[3] Arunrat, N., Wang, C., Pumijumnong, N. (2016): Alternative cropping systems for greenhouse gases mitigation in rice field: a case study in Phichit province of Thailand. Journal of Cleaner Production 133: 657-671.

[4] Aulakh, M. S., Wassmann, R., Rennenberg, H. (2001): Methane emissions from rice fields-quantification, role of management, and mitigation options. - Advances in Agronomy 70: 193-260.

[5] Birhane, A. (2013): Effect of planting methods on yield and yield components of rice (Oryza sativa L.) varieties in Tahtay Koraro Wereda, Northern Ethiopia. - International Journal of Technology Enhancements and Emerging Engineering Research 1(5).

[6] Bozorgi, H. R., Faraji, A., Danesh, R. K. (2011): Effect of plant density on yield and yield components of rice. - World Applied Sciences Journal 12(11): 2053-2057.

[7] Chandankute, R. K., Verma, V. K., Meena, R. N., Meena, K. C., Singh, R. K. (2015): Effect of various crop establishment method and integrated nutrient management on 
growth, yield and economics of rice (Oryza sativa L.). - Journal of Pure and Applied Microbiology 9(4): 2997-3003.

[8] Chen, S., Yin, M., Zheng, X., Liu, S., Chu, G., Xu, C., Wang, D., Zhang, X. (2019): Effect of dense planting of hybrid rice on grain yield and solar radiation use in Southeastern China. - Agronomy Journal 111: 1229-1238.

[9] Dileep, K., Pasupalak, S., Baliarsingh, A. (2018): Effect of establishment methods and sowing time on growth and yield of rice varieties (Oryza sativa L.). - The Pharma Innovation Journal 7(4): 904-907.

[10] Fagade, S. O., De Datta, S. K. (1971): Leaf area index, tillering capacity, and grain yield of tropical rice as affected by plant density and nitrogen level. - Agronomy Journal 63: 503-506.

[11] Fazli, P., Man, H. C. (2014): Comparison of methane emission from conventional and modified paddy cultivation in Malaysia. - Agriculture and Agricultural Science Procedia 2: $272-279$.

[12] Gautam, P., Lal, B., Nayak, A. K., Raja, R., Panda, B. B., Tripathi, R., Shahid, M., Kumar, U., Baig, M. J., Chatterjee, D., Swain, C. K. (2019): Inter-relationship between intercepted radiation and rice yield influence by transplanting time, method, and variety. - International Journal of Biometeorology 63: 337-349.

[13] Geethalakshmi, V., Bhuvaneswari, K., Lakshmanan, A., Sekhar, N. U. (2017): Assessment of climate change impact on rice using controlled environment chamber in Tamil Nadu, India. - Current Science 112(10).

[14] Gholizadeh, A., Saberioon, M., Boruvka, L., Wayayok, A., Soom, M. A. M. (2017): Leaf chlorophyll and nitrogen dynamics and their relationship to lowland rice yield for sitespecific paddy management. - Information Processing in Agriculture 4: 259-268.

[15] Ghosh, M., Swain, D. K., Jha, M. K., Tewari, V. K., Bohra, A. (2020): Optimizing chlorophyll meter (SPAD) reading to allow efficient nitrogen use in rice and wheat under rice-wheat cropping system in eastern India. - Plant Production Science 23(3): 270-285.

[16] GRiSP (2013): The Global Rice Science Partership. Rice Almanac. ${ }^{\text {th }}$ Ed. International Rice Research Institute, Los Banos (Philippines).

[17] Guo, J., Hu, X., Gao, L., Xie, K., Ling, N., Shen, Q., Hu, S., Guo, S. (2017): The rice production practices of high yield and high nitrogen use efficiency in Jiangsu, China. Scientific Reports. 7: 2101.

[18] Hasanuzzaman, M., Ahamed, K. U., Rahmatullah, N. M., Akhter, N., Nahar, K., Rahman, M. L. (2010): Plant growth characters and productivity of wetland rice (Oryza sativa L.) as affected by application of different manures. - Emirates Journal of Food and Agriculture 22(1): 46-58.

[19] Hirooka, Y., Homma, K., Maki, M., Sekiguchi, K., Shiraiwa, T., Yoshida, K. (2017): Evaluation of the dynamics of the leaf area index (LAI) of rice in farmer's fields in Vientiane Province, Lao PDR. - Journal of Agricultural Meteorology 73(1): 16-21.

[20] Hom, N. H., Htwe, N. M., Hein, Y., Than, S. M., Kywe, M., Htut, T. (2015): Myanmar Climate-Smart Agriculture Strategy. - CGIAR Research Program on Climate Change, Agriculture and Food Security (CCAFS), International Rice Research Institute (IRRI). Ministry of Agriculture and Irrigation (MOAI), Naypyitaw, Myanmar. https://ccafs.cgiar. org/resources/publications/myanmar-climate-smart-agriculture-strategy.

[21] Hossain, M. F., Salam, M. A., Uddin, M. R., Pervez, Z., Sarkar, M. A. R. (2002): A comparative study of direct seeding versus transplanting method on the yield of Aus rice. - Pakistan Journal of Agronomy 1(2-3): 86-88.

[22] Huang, M., Zou, Y., Jiang, P., Xia, B., Feng, Y., Cheng, Z., Mo, Y. (2011): Yield component differences between direct-seeded and transplanted super hybrid rice. - Plant Production Science 14(4): 331-338. 
[23] Huang, M., Yang, C., Ji, Q., Jiang, L., Tan, J., Li, Y. (2013): Tillering responses of rice to plant density and nitrogen rate in a subtropical environment of southern China. - Field Crops Research 149: 187-192.

[24] Ilahi, S., Wu, Y., Raza, M. A. A., Wei, W., Imran, M., Bayasgalankhuu, L. (2019): Optimization approach for improving energy efficiency and evaluation of greenhouse gas emission of wheat crop using data envelopment analysis. - Sustainability 11: 3409 .

[25] IPCC (2006): Guidelines for National Greenhouse Gas Inventories. - Intergovernmental Panel on Climate Change, Geneva.

[26] IPCC (2007): Climate Change 2007: The Physical Science Basis. IPCC Fourth Assessment Report (AR4). Contribution of Working Group 1 to the Fourth Assessment Report of the Intergovernmental Panel on Climate Change. - Intergovernmental Panel on Climate Change, Geneva.

[27] Iqbal, A., He, L., Khan, A., Wei, S., Akhtar, K., Ali, I., Ullah, S., Munsif, F., Zhao, Q., Jiang, L. (2019): Organic manure coupled with inorganic fertilizer: an approach for the sustainable production of rice by improving soil properties and nitrogen use efficiency. Agronomy 9: 651.

[28] Ishfaq, M., Akbar, N., Anjum, S. A., Anwar-Ul-Haq, M. (2020): Growth, yield and water productivity of dry direct seeded rice and transplanted aromatic rice under different irrigation management regimes. - Journal of Integrative Agriculture 19(11): 2656-2673.

[29] Islam, S. F-U., Groenigen, J. W. V., Jensen, L. S., Sander, B. O., Neergaard, A. D. (2018a): The effective mitigation of greenhouse gas emissions from rice paddies without compromising yield by early-season drainage. - Science of The Total Environment 612: 1329-1339.

[30] Islam, S. M. M., Gaihre, Y. K., Biswas, J. C., Singh, U., Ahmed, M. N., Sanabria, J., Saleque, M. A. (2018b): Nitrous oxide and nitric oxide emissions from lowland rice cultivation with urea deep placement and alternate wetting and drying irrigation. Scientific Reports 8: 17623.

[31] Javaid, T., Awan, I. U., Baloch, M. S., Shah, I. H., Nadim, M. A., Khan, E. A., Khakwani, A. A., Abuzar, M. R. (2012): Effect of planting methods on the growth and yield of coarse rice. - Journal of Animal and Plant Sciences 22(2): 358-362.

[32] Kar, I., Yadav, S., Mishra, A., Behera, B., Khanda, C., Kumar, V., Kumar, A. (2018): Productivity trade-off with different water regimes and genotypes of rice under nonpuddled conditions in Eastern India. - Field Crops Research 222: 218-229.

[33] Kesh, H., Ram, K., Jangid, K. (2017): System of rice intensification: a review on resource conserving method of rice crop establishment. - International Journal of Current Microbiology and Applied Sciences 6(11): 2315-2328.

[34] Kramer, D. M., Jhonson, G., Kiirats, O., Edwards, G. E. (2004): New fluorescence parameters for the determination of $\mathrm{Q}_{\mathrm{A}}$ redox state and excitation energy fluxes. Photosynthesis Research 79: 209-218.

[35] Kuhlgert, S., Austic, G., Zegarac, R., Osei-Bonsu, I., Hoh, D., Chilvers, M. I., Roth, M. G., Bi, K., TerAvest, D., Weebadde, P., Kramer, D. M. (2016): MultispeQ Beta: a tool for large-scale plant phenotyping connected to the open PhotosynQ network. - Royal Society Open Science 3: 160592.

[36] Kumhar, B. L., Chavan, V. G., Rajemahadik, V. A., Kanade, V. M., Dhopavkar, R. V., Ameta, H. K., Tilekar, R. N. (2016): Effect of different rice establishment methods on growth, yield and different varieties during Kharif season. - International Journal of Plant, Animal and Environmental Sciences 6(2): 127-131.

[37] Lal, R. (2004): Carbon emission from farm operations. - Environment International 30: 981-990. 
[38] Lancashire, P. D., Bleiholder, H., Boom, T. V. D., Langeluddeke, P., Stauss, R., Weber, E., Witzenberger, A. (1991): A uniform decimal code for growth stages of crops and weeds. - Annals of Applied Biology 119: 561-601.

[39] Linquist, B. A., Adviento-Borbe, M. A., Pittelkow, C. M., Kessel, C. V., Groenigen, K. J. V. (2012): Fertilizer management practices and greenhouse gas emissions from rice systems: a quantitative review and analysis. - Field Crops Research 135: 10-21.

[40] Liu, H., Hussain, S., Zheng, M., Peng, S., Huang, J., Cui, K., Nie, L. (2015): Dry directseeded rice as an alternative to transplanted-flooded rice in Central China. - Agronomy for Sustainable Development 35(1): 285-294.

[41] Ly, P., Jensen, L. S., Bruun, T. B., Neergaard, A. D. (2013): Methane $\left(\mathrm{CH}_{4}\right)$ and nitrous oxide $\left(\mathrm{N}_{2} \mathrm{O}\right)$ emissions from the system of rice intensification (SRI) under a rain-fed lowland rice ecosystem in Cambodia. - Nutrient Cycling in Agroecosystems 97: 13-27.

[42] Millar, N., Doll, J. E., Robertson, G. P. (2014): Management of Nitrogen Fertilizer to Reduce Nitrous Oxide $\left(\mathrm{N}_{2} \mathrm{O}\right)$ Emissions from Field Crops. - Climate Change and Agriculture Fact Sheet Series - MSU Extension Bulletin E3152. Michigan State University, Michigan.

[43] MOALI (2016): Ministry of Agriculture, Livestock and Irrigation. - Myanmar Agriculture Sector in Brief, Myanmar.

[44] Mohamad, O., Suhaimi, O., Abdullah, M. Z. (1994): The relationships between harvest index, grain yield and biomass in rice. - MARDI Res. J 22(1): 29-34.

[45] MRDS (2015): Myanmar Rice Sector Development Strategy. - Naypyitaw, Myanmar.

[46] Myint, A. K., Yamakawa, T., Zenmyo, T., Thao, H. T. B., Sarr, P. S. (2011): Effects of organic-manure application on growth, grain yield, and nitrogen, phosphorus, and potassium recoveries of rice variety Manawthukha in paddy soils of differing fertility. Communications in Soil Science and Plant Nutrition 42(4): 457-474.

[47] Nahar, L., Sarker, A. B. S., Mahbub, M. M., Akter, R. (2018): Effect of crop establishment method and nutrient management on yield and yield attributes of short duration T. Aman rice. - Bangladesh Agronomy Journal 21(1): 117-123.

[48] Ndikuryayo, C., Ochwo-Ssemakula, M., Gibson, P., Lamo, J. (2020): Resistance to rice yellow mottle virus and performance of selected improved rice genotypes in central Uganda. - Crop Protection 129: 105041.

[49] Oo, A. Z., Win, K. T., Motobayashi, T., Bellingrath-Kimura, S. D. (2016): Effect of cattle manure amendment and rice cultivars on methane emission from paddy rice soil under continuously flooded conditions. - Journal of Environmental Biology 37: 10291036.

[50] Pimratch, S., Butsat, S., Kesmala, T. (2015): Application of blue-green and mineral fertlizers to direct seeding lowland rice. - ScienceAsia 41: 305-314.

[51] Pokhrel, A., Soni, P. (2019): Energy balance and environmental impacts of rice and wheat production: a case study in Nepal. - International Journal of Agricultural and Biological Engineering 12(1): 201-207.

[52] Promsomboon, P., Sennoi, R., Puthmee, T., Marubodee, R., Ruanpan, W., Promsomboon, S. (2019): Effect of seedlings numbers per hill on the growth and yield of Kum Bangpra rice variety (Oryza sativa L.). - International Journal of Agricultural Technology 15(1): 103-112.

[53] Ramesh, T., Rathika, S. (2020): Evaluation of rice cultivation systems for greenhouse gases emission and productivity. - International Journal of Ecology and Environmental Sciences 2(2): 49-54.

[54] Ramesh, K., Chandrasekaran, B., Balasubramanian, T. N., Bangarusamy, U., Sivasamy, R., Sankaran, N. (2002): Chlorophyll dynamics in rice (Oryza sativa) before and after 
flowering based on SPAD (chlorophyll) meter monitoring and its relation with grain yield. - Journal of Agronomy and Crop Science 188: 102-105.

[55] Rana, M. M., Mamun, M. A. A., Zahan, A., Ahmed, M. N., Mridha, M. A. J. (2014): Effect of planting methods on yield and yield attributes of short duration Aman Rice. American Journal Plant Sciences 5: 251-255.

[56] Ren, F., Zhang, X., Liu, J., Sun, N., Wu, L., Li, Z., Xu, M. (2017): A synthetic analysis of greenhouse gas emissions from manure amended agricultural soils in China. Scientific Reports 7: 8123.

[57] Roberts, D. P., Mattoo, A. K. (2018): Sustainable agriculture- enhancing environmental benefits, food nutritional quality and building crop resilience to abiotic and biotic stresses. - Agriculture 8(8).

[58] Savvides, A. M., Fotopoulos, V. (2018): Two inexpensive and non-destructive techniques to correct for smaller-than-gasket leaf area in gas exchange measurements. Frontiers in Plant Science 9: 548.

[59] Sen, A., Sarkar, M. A. R., Begum, M., Zaman, F., Ray, S. (2014): Effect of spacing and weed management on the growth of BRRI dhan56. - International Journal of Experimental Agriculture 4(3): 20-29.

[60] Shanker, A. K., Coe, R., Sirault, X. (2019): Integrated high-resolution phenotyping, chlorophyll fluorescence induction kinetics and photosystem II dynamics under water stress and heat in wheat (Triticum aestivum). - bioRxiv. http://dx.doi.org/10.1101/ 510701.

[61] Shrestha, S. P. (2012): Genotypic responses of upland rice to an altitudinal gradient. $\mathrm{PhD}$ Thesis, University of Hohenheim, Hohenheim.

[62] Singh, K. L., Devi, K. N., Athokpam, H. S., Singh, N. B., Sagolshem, K. S., Meetei, W. H., Mangang, C. A. (2014): Effect of cultivars and planting geometry on weed infestation, growth and yield in transplanted rice. - An International Quarterly Journal of Environmental Sciences 8(1-2): 1-5.

[63] Stoop, W. A., Uphoff, N., Kassam, A. (2002): A review of agricultural research issues raised by the system of rice intensification (SRI) from Madagascar: opportunities for improving farming systems for resource-poor farmers. - Agricultural Systems 71: 249274.

[64] Tanaka, A., Kawano, K. (1995): Leaf characters relating to nitrogen response in the rice plant. - Soil Science and Plant Nutrition 11(6): 31-38.

[65] Thakur, A. K., Uphoff, N., Antony, E. (2010a): An assessment of physiological effects of system of rice intensification (SRI) practices compared with recommended rice cultivation practices in India. - Experimental Agriculture 46(1): 77-98.

[66] Thakur, A. K., Rath, S., Roychowdhury, S., Uphoff, N. (2010b): Comparative performance of rice with system of rice intensification (SRI) and conventional management using different plant spacings. - Journal of Agronomy and Crop Science 196: 146-159.

[67] Tomar, R., Singh, N. B., Singh, V., Kumar, D. (2018): Effect of planting methods and integrated nutrient management on growth parameters, yield and economics of rice. Journal of Pharmacognosy and Phytochemistry 7(2): 520-527.

[68] Traore, B., Samake, F., Babana, A., Hang, M. (2017): Effects of different fertilizers on methane emission from paddy field of Zhejiang, China. - African Journal of Environmental Science and Technology 11(1): 89-93.

[69] Tubiello, F. N., Condor-Golec, R. D., Salvatore, M., Piersante, A., Federici, S., Ferrara, A., Rossi, S., Flammini, A., Cardenas, P., Biancalani, R., Jacobs, H., Prasula, P., Prosperi, P. (2015): Estimating Greenhouse Gas Emissions in Agriculture. A Manual to 
Address Data Requirements for Developing Countries. - Food and Agriculture Organization of the United Nations, Rome.

[70] Wang, W., Lai, D. Y. F., Wang, C., Tong, C., Zeng, C. (2016): Effects of inorganic amendments, rice cultivars and cultivation methods on greenhouse gas emissions and rice productivity in a subtropical paddy field. - Ecological Engineering 95: 770-778.

[71] Yi-hu, M., Dao-jian, G., Li-jun, L., Zhi-qin, W., Hao, Z., Jian-chang, Y. (2014): Changes in grain yield of rice and emission of greenhouse gases from paddy fileds after application of organic fertilizer made from maize straw. - Rice Science 21(4): 224-232.

[72] Yodkhum, S., Sampattagul, S., Gheewala, S. H. (2018): Energy and environmental impact analysis of rice cultivation and straw management in northern Thailand. Environmental Science and Pollution Research 25: 17654-17664.

[73] Yoshida, S. (1981): Fundamentals of Rice Crop Science. - The International Rice Research Institute (IRRI). Philippines.

[74] Yuan, Z., Cao, Q., Zhang, K., Ata-Ul-Karim, S. T., Tian, Y., Zhu, Y., Cao, W., Liu, X. (2016): Optimal leaf positions for SPAD meter measurement in rice. - Frontiers in Plant Science 7: 719. 